\title{
The relationship between blood serum and seminal plasma cholesterol content in young boars and their semen qualitative traits and testes size
}

\author{
EUGENIA JACYNO ${ }^{1}$, ANITA KOŁODZIEJ' ${ }^{1}$, MARIA KAWĘCKA ${ }^{1}$, ARKADIUSZ PIETRUSZKA ${ }^{1}$, \\ BEATA MATYSIAK ${ }^{1}$ and MARIAN KAMYCZEK ${ }^{2}$
}

'Department of Pig Breeding, University of Agriculture, Szczecin, Poland, ${ }^{2}$ National Research Institute of Animal Production, Kraków, Poland

\section{Abstract}

The relationship between blood serum and seminal plasma cholesterol concentration and semen traits and testes size was examined on 110 young boars (6 month old) of the 990 synthetic line. In the study were determined: testes volume, semen quality traits (ejaculate volume, motile spermatozoa percentage, spermatozoa concentration and total number per ejaculate, percentage of spermatozoa with normal acrosome, percentage of spermatozoa with major and minor morphological defects, osmotic resistance test value [ORT] and activity of aspartate aminotransferase in seminal plasma [AspAT]). Cholesterol content in blood serum and seminal plasma were determined. Mean cholesterol content in blood serum amounted to 71.2 , while that in seminal plasma to $6.96 \mathrm{mg} / \mathrm{dL}$. Total cholesterol content in blood serum correlated positively with testes volume $(P \leq 0.05)$, whereas no correlation was found with semen quality traits of the examined males. Cholesterol concentration in seminal plasma was positively correlated $(P \leq 0.05)$ with spermatozoa motility, concentration and total number, while negatively $(P \leq 0.05)$ with the percentage of spermatozoa with major morphological defects and the activity of AspAT in seminal plasma. No relationship was found between total cholesterol content in blood serum and that in seminal plasma.

Keywords: blood serum, seminal plasma, cholesterol, boar, semen traits, correlation

\section{Zusammenfassung}

\section{Beziehungen zwischen dem Cholesteringehalt im Blut- und Seminalplasma sowie Spermamerkmalen und der Hodengröße}

Die Untersuchungen erfolgten an 110 sechs Monate alten Jungebern der synthetischen Linie 990. Erfasst wurden neben dem Cholesteringehalt im Blut- und Samenplasma die Merkmale: Hoden- und Ejakulatvolumen, Spermienkonzentration, Gesamtspermienzahl, Anteil beweglicher Spermien, Anteil Spermien mit normalem Akrosom, Anteil Spermien mit geringen oder größeren Defekten, Osmoseresistenztest (ORT) sowie die Aktivität der Aspartat-Aminotransferase (AST) im Seminalplasma. Der durchschnittliche Cholesteringehalt betrug im Serum 71,2 und im Seminalplasma 6,96 mg/dL. Zwischen den Cholesterinwerten im Blut- und Seminalplasma ergaben sich keine Beziehungen. Der Gesamtcholesteringehalt im Blutserum korrelierte positiv mit dem Hodenvolumen 
jedoch konnten keine Zusammenhänge mit den Spermamerkmalen nachgewiesen werden. Die Cholesterinkonzentration im Seminalplasma war positiv mit dem Anteil beweglicher Spermien, der Spermienkonzentration, der Gesamtspermienzahl und negativ mit dem Anteil Spermien mit größeren Defekten und der AST Aktivität korreliert.

Schlüsselwörter: Schwein, Eber, Blutserum, Seminalplasma, Cholesterin, Korrelation Spermamerkmale

\section{Introduction}

Cholesterol is the main sterol in ejaculated mammalian semen being principally situated in cellular membranes, with its largest quantities being found the plasmatic membrane (YEAGLE 1993). High quantities of that sterol are synthesised in epididymia, from where it is transported to the plasmatic membrane during spermatozoa maturation (YANAGIMACHI 1994). Sperm plasmatic membranes of different animal species are characterised by variable cholesterol content. Boar sperm membranes contain much less cholesterol when compared to other species (PARKS and LYNCH 1992). The cholesterol/ phospholipid (C/PL) ratio in boar sperm plasmatic membranes is the lowest and amounts to 0.20 (PARKS and HAMMERSTEDT 1985, MACK et al. 1986, HALL et al. 1991). This is a reason of their exceptional susceptibility to osmotic and cold strokes (STRZEŻEK 1999). Positive correlations were found between the C/PL ratio and the percentage of live and normal spermatozoa after $2 \mathrm{~h}$ from boar semen thawing (LABBÉ et al. 2001).

In some animal species, the concentration of cholesterol in sperm plasmatic membrane changes during its transport through epididymia - it increases in ram and billy goat (PARKS and HAMMERSTEDT 1985, MACK et al. 1986), decreases in rat and stallion (HALL et al. 1991, LOPEZ and SOUZA 1991), whereas does not change in boar (NIKOLOPOULOU et al. 1985). Cholesterol regulate the fluidity of the sperm membrane during epididymal maturation and later during capacitation and acrosome reaction in the female genital tract (NIKOLOPOULOU et al. 1985).

Cholesterol is a precursor to several important steroid hormones secreted by the adrenal cortex, ovaries, and testes. WISE et al. (1993) found a positive correlation between cholesterol concentration and that of testosterone in blood serum of boars. This hormone stimulates the growth and development of genital organs as well as spermatogenesis and sexual activity.

At present, in pig production are used the boars that are characterised by high growth rate and considerable meatiness. At the same time, however, a worsening of their reproductive traits is observed. The findings of some research works suggest that selection towards pig meatiness increase and fatness decrease may result in the lowering of cholesterol level in blood (JANIK 1997, FALKENBERG et al. 1999). Certain studies (FALKENBERG et al. 1995, KAWĘCKA 2002, KOŁODZIEJ et al. 2006) showed a relationship between blood cholesterol level and reproductive traits in boars, with this relationship being however not clear-cut. Examinations indicate that there is also a connection between spermatozoa cholesterol content and certain qualitative traits in male semen (CEROLINI et al. 1997, MACHAL et al. 1996). The ejaculated sperm can receive an additional portion of cholesterol from seminal plasma (CROSS 1998). 
In the presented research work, carried out on young (6 month old) boars, a relationship between blood serum and seminal plasma cholesterol concentration and semen quantitative and qualitative traits and testes size in the examined males.

\section{Material and methods}

\section{Animals and experimental procedures}

The studies were carried out at the State Center of Pig Hybridization in Poland on the 110 young (6 month old) boars of synthetic line 990. From the day of weaning (from day 30) until day 63 of life, the young boars were still kept in farrowing pens and were fed with a feed mixture, according to the Polish Norm of Pigs Nutrition (1993). On day 63, after preliminary selection, the males were sent to test evaluation that started on day 180 of life. In that period of time, they were housed in bedding-free individual pens $(1 \times 2 \mathrm{~m})$ with partly slatted floor (about $40 \%$ ) and equipped with drinkers. The animals were fed in that period of time with a feed mixture (Table 1) prepared in the form of pellets. The daily ration of feed was increased together with an increase in the body weight of evaluated animals.

Table 1

Nutritive value of diet

Futterwert der Futtermischung

\begin{tabular}{lc}
\hline Specification & $\ln 1 \mathrm{~kg}$ diet \\
\hline Metabolizable energy, MJ & 12.7 \\
Crude protein, g & 191 \\
Crude fibre, g & 27 \\
Lysine, g & 10.1 \\
Methionine + cystine, g & 6.4 \\
Threonine, g & 6.7 \\
Tryptophan, g & 2.0 \\
Vitamin and mineral mixture & $*$ \\
\hline
\end{tabular}

* per kg diet: $7700 \mathrm{IU} \mathrm{A}, 2100 \mathrm{IU} \mathrm{D} 3,30 \mathrm{mg} \mathrm{E}, 1.5 \mathrm{mg} \mathrm{K} 3,1.05 \mathrm{mg} \mathrm{B} 1,3.6 \mathrm{mg} \mathrm{B2}, 2.1 \mathrm{mg} \mathrm{B} 6,0.021 \mathrm{mg} \mathrm{B12,} 15 \mathrm{mg}$ nicotynic acid, $1.05 \mathrm{mg}$ calcium pantothenate, $0.45 \mathrm{mg}$ folic acid, $0.021 \mathrm{mg}$ biotin, $300 \mathrm{mg}$ cholin chloride, 100.5 $\mathrm{mg} \mathrm{Zn,} 30 \mathrm{mg} \mathrm{Mn}, 21 \mathrm{mg} \mathrm{Cu}, 75 \mathrm{mg} \mathrm{Fe}, 0.6 \mathrm{mg} J 2,0.2 \mathrm{mg} \mathrm{Se}$

On day 180 of life, the volume of boar testes was assessed (YOUNG et al. 1986) and the collection of semen was started by means of manual method. The evaluation of semen was carried out on three ejaculates, collected in at least 7-day long time intervals. During semen collection, also blood was called from the males, from the jugular vein.

\section{Semen evaluation}

Shortly after collection and filtration of ejaculate, its following characteristics were determined: ejaculate volume, percentage of progressively motile spermatozoa (subjectively method with Nikon microscope) concentration of spermatozoa in $1 \mathrm{ml}$ (cytometric method in Bürker's chamber), and total number of spermatozoa in ejaculate. The minor and major morphological changes of the semen (according to BLOM 1981) and percentage spermatozoa with normal acrosome ridge - NAR (according to PURSEL et al. 1972) were 
determined in the preparations coloured by eosin and nigrosin. The ORT of acrosomal membranes was performed according to SCHILLING and VENGUST (1987). To carry out the ORT, two samples of semen were collected, $0.2 \mathrm{ml}$ each. One sample was thinned out with $3 \mathrm{ml} \mathrm{BTS}$-Beltsville Thawing Solution $(300 \mathrm{mOsm} / \mathrm{kg}$ ) and incubated for $15 \mathrm{~min}$ at $39^{\circ} \mathrm{C}$. Another sample was infused with $3 \mathrm{ml} \mathrm{BTS}$ and then diluted with distilled water to $150 \mathrm{mOsm} / \mathrm{kg}$ and incubated for $120 \mathrm{~min}$ at $39^{\circ} \mathrm{C}$. After incubation of samples and preparation of stained smears, the percentage of spermatozoa with normal acrosome ridge (NAR) was determined. The ORT was calculated according to the formula:

$$
\mathrm{ORT}=\frac{1}{2} \text { [\%NAR in } 300 \mathrm{mOsm} \text { (for } 15 \mathrm{~min} \text { )+\%NAR in } 150 \mathrm{mOsm} \text { (for } 120 \mathrm{~min} \text { )] }
$$

The activity of AspAT in seminal plasma was determined by kinetic method with spectrophotometer Model PRO-Bio, Marcel (reagents Bio Merieux Corp.) AspAT activity was converted as per $1 \cdot 10^{9}$ of spermatozoa.

\section{Blood serum and seminal plasma preparation and cholesterol assay}

The blood samples were allowed to clot at room temperature for $6 \mathrm{~h}$. The serum was separated by centrifugation at $3000 \mathrm{xg}$ for $10 \mathrm{~min}$. The seminal plasma was obtained by centrifugation ( $2000 \mathrm{x}$ for $10 \mathrm{~min}$ ) of the fluid fraction of the semen. Serum and seminal plasma were stored frozen at $-20^{\circ} \mathrm{C}$ until analysis. Serum and seminal plasma total cholesterol was determined by enzymatic method (ALLAIN et al. 1974). Absorbance was measured by spectrophotometer (Model PRO-Bio, Marcel) at a wavelength of $500 \mathrm{~nm}$ (reagents Alpha Diagnostics Corp.).

\section{Statistical analysis}

Data was analysed using the Statistica 6.0 PL software. Correlation coefficients were calculated between blood serum and seminal plasma cholesterol content and testes volume and semen traits (ejaculate volume, concentration and total number of spermatozoa in ejaculate, percentage of motile spermatozoa, major and minor morphological changes of spermatozoa, rate of acrosome defects, ORT and activity of AspAT.

\section{Results}

The values of semen traits, blood serum and seminal plasma total cholesterol (means of three sample collections from 110 boars) and testes volume of the examined males are presented in Table 2. The cholesterol content in blood serum ranged $45.2-92.8 \mathrm{mg} / \mathrm{dL}$ (mean 71.2), whereas that in seminal plasma $2.8-16.9 \mathrm{mg} / \mathrm{dL}$ (mean 6.96). The volume of testes and semen traits are characteristic of young boars (FALKENBERG and RITTER 1992, 1994, KAWĘCKA 2002). The ejaculates were characterised by relatively large number of spermatozoa with morphological defects $(13.9 \%$ spermatozoa with major defects and $11.2 \%$ with minor defects on the average). Most frequently occurring morphological defects were protoplasmatic droplets in proximal and distal position. 
Table 2

Blood serum and seminal plasma total cholesterol content, testes volume and semen traits of young boars

Cholesteringehalt im Blutserum und Seminalplasma, Hodenvolumen und Spermamerkmale von Jungebern

\begin{tabular}{lcc}
\hline Item & Mean & SD \\
\hline Blood serum cholesterol, $\mathrm{mg} / \mathrm{dL}$ & 71.2 & 12.27 \\
Seminal plasma cholesterol, $\mathrm{mg} / \mathrm{dL}$ & 6.96 & 3.08 \\
Volume of both testes, $\mathrm{cm}^{3}$ & 254 & 81.9 \\
Ejaculate volume, $\mathrm{cm}^{3}$ & 110 & 9.0 \\
Motile spermatozoa, $\%$ & 72.6 & 5.24 \\
Concentration of spermatozoa, $\left.n \cdot 10^{6} / \mathrm{cm}^{3}\right)$ & 205 & 77.1 \\
Total number of spermatozoa, $n \cdot 10^{9}$ & 22.6 & 6.46 \\
Spermatozoa with major defects, $\%$ & 13.9 & 6.13 \\
Spermatozoa with minor defects, $\%$ & 11.2 & 6.45 \\
Spermatozoa with normal acrosome, $\%$ & 83.3 & 8.54 \\
ORT, \% & 65.9 & 5.44 \\
AspAT, mU $/ 10^{9}$ spermatozoa & 124 & 32.2 \\
\hline
\end{tabular}

The estimated coefficients of correlation are presented in Table 3. The content of total cholesterol in blood serum significantly positively correlated $(P \leq 0.05)$ with the volume of testes of the examined boars. On the other hand, the coefficients of correlation between blood serum cholesterol level in and semen traits are small. No correlation was found either between total cholesterol content in blood serum and that in seminal plasma.

It was showed that seminal plasma total cholesterol level was significantly positively correlated $(P \leq 0.05)$ with spermatozoa motility, concentration and total number, while being negatively correlated $(P \leq 0.05)$ with the percentage of spermatozoa with major morphological defects and the activity of aspartate aminotransferase (AspAT) in seminal plasma. Other coefficients of correlation were statistically non-significant.

Table 3

Correlation coefficients between blood serum and seminal plasma total cholesterol content and testes volume and semen traits

Korrelation zwischen dem Gesamtcholesteringehalt im Blutserum und Seminalplasma sowie dem Hodenvolumen und den Spermamerkmalen

\begin{tabular}{lcc}
\hline \multirow{2}{*}{ Item } & \multicolumn{2}{c}{ Cholesterol in } \\
& blood serum & seminal plasma \\
\hline Blood serum cholesterol & - & 0.037 \\
Seminal plasma cholesterol & 0.037 & - \\
Volume of both testes & $0.195^{*}$ & -0.088 \\
Ejaculate volume & 0.065 & -0.069 \\
Motile spermatozoa & 0.070 & $0.217^{*}$ \\
Concentration of spermatozoa & 0.076 & $0.225^{*}$ \\
Total number of spermatozoa & 0.087 & $0.196^{*}$ \\
Spermatozoa with major defects & -0.031 & $-0.154^{*}$ \\
Spermatozoa with minor defects & -0.096 & -0.010 \\
Spermatozoa with normal acrosome & 0.062 & 0.067 \\
ORT & 0.002 & 0.122 \\
AspAT & 0.082 & $-0.215^{*}$ \\
\hline
\end{tabular}

${ }^{*} P \leq 0.05$ 


\section{Discussion}

The content of total cholesterol in blood serum and seminal plasma of the examined boars is similar to the values given for boars by other authors (LABBÉ et al. 2001, KAWĘCKA 2002). The seminal plasma of boars contains relatively small amount of cholesterol (KOMMISRUD et al. 2002), which was also confirmed by the present study. The concentration of cholesterol in human seminal plasma amounts to $25 \mathrm{mg} / \mathrm{dL}$ (CROSS 1996), whereas it was several times smaller in the seminal plasma of boars under present examination. Cholesterol is secreted to seminal plasma by the prostate gland and it protects sperm cells against environmental shock (SOFIKITIS and MIYAGAWA 1991).

Since cholesterol is a precursor of many steroid hormones responsible for reproduction, it can be assumed that an increase of cholesterol level in blood will increase steroid production and the same will improve reproductive traits. This hypothesis was not confirmed in the presented study. Low negative and positive phenotypical correlations between sprermatozoa activity, ejaculate volume, spermatozoa concentration and plasma cholesterol concentration were also found out in cocks (MACHAL et al. 1996). However, KAWĘCKA (2002) showed in the study on boars that the level of cholesterol in blood serum significantly negatively correlated with ORT value and AspAT activity, whereas its coefficients of correlation with the value of other semen traits examined approximated zero (similarly as in the present study). The results obtained in the present study indicated that larger cholesterol content in blood serum was accompanied by larger volume of boar testes, whereas RIBEIRO et al. (1994) found in mice a negative (but statistically non-significant) correlation $(r=-0.12)$ between blood cholesterol level and testes weight.

Closer (positive) relationship occurred between the cholesterol concentration in seminal plasma and its quality. Larger amount of cholesterol in seminal plasma was accompanied by larger concentration and total number of spermatozoa in the ejaculate. In the ejaculates with larger cholesterol content in seminal plasma was found a significantly lower percentage of spermatozoa with major morphological defects. Major morphological defects of spermatozoa result in a significant decrease of male fertility (BLOM 1981). The main trait of boar semen quality, determining its fertilisation ability, is motile spermatozoa percentage. In the boars under present examination was found a positive relationship between seminal plasma cholesterol content and spermatozoa motility, whereas in poultry a negative correlation $(r=-0.279)$ was reported between spermatozoa motility and sperm cholesterol content (CEROLINI et al. 1997).

Additional information on the quality of semen and its fertilisation ability is provided by ORT. It determines a degree of susceptibility of sperm acrosomal membranes to osmotic pressure changes. With larger cholesterol content, boar spermatozoa membranes show an increased resistance to osmotic strokes (STRZEŻEK 1999). In the presented study, a positive relationship $(r=0.122)$ was also observed between seminal plasma cholesterol concentration and ORT value.

AspAT is permanently connected with the sperm basal body, in particular its with mitochondrial membrane. The increased outflow of AspAT from sperm cells to seminal plasma points to a damage of spermatozoa within mitochondrial system and to an increase in permeability of their cellular membrane (CIERESZKO et al. 1992). The results of 
the present study show that larger cholesterol concentration is accompanied by lower AspAT activity in seminal plasma. There is a close negative relationship between AspAT activity in seminal plasma and spermatozoa motility (BRONICKA and DEMBIŃSKI 1999), which is also confirmed by the presented study. The boar ejaculates with larger cholesterol content in seminal plasma were characterised by lower AspAT activity and larger percentage of motile spermatozoa.

No relationship was found between the content of cholesterol in blood serum and that in seminal plasma of the boars under present examination, which is consistent with the findings of other authors (GRIZARD et al. 1995, LABBÉ et al. 2001). There appears to be no correlation between the amount of cholesterol in blood serum and that in sperm or seminal plasma, suggesting that sperm cholesterol content is regulated locally within the male reproductive tract (GRIZARD et al. 1995).

\section{References}

Allain CC, Poon LS, Chan CS, Richmond W, FU PC (1974) Enzymatic determination of total serum cholesterol. Clin Chem 20, 470-5

Blom E (1981) Studies on seminal vesiculitis in the bull: II Proposal for a new classification of the spermiogram. Medycyna Wet 4, 239-42 [in Polish]

Bronicka A, Dembiński Z (1999) Current criteria and conditions influencing the quality of boar semen Medycyna Wet 550, 436-9 [in Polish]

Cerolini S, Kelso KA, Noble RC, Speake BK, Pizzi F, Cavalchini LG (1997) Relationship between spermatozoan lipid composition and fertility during aging of chickens. Biol Reprod 57, 976-80

Ciereszko A, Glogowski J, Strzeżek J, Demianowicz W (1992) Low stability of aspartate aminotransferase activity in boar semen. Theriogenology $37,1269-81$

Cross NL (1996) Human seminal plasma prevents sperm from becoming acrosomally responsive to the agonist progesterone: cholesterol is the major inhibitor. Biol Reprod 54, 138-45

Cross NL (1998) Role of cholesterol in sperm capacitation. Biol Reprod 59, 7-11

Falkenberg H, Nürnberg K, Kuhn G, Nürnberg G (1995) Cholesterol level in blood and in fatty tissue and their relations to carcass and meat quality of pigs. Arch Tierz 38, 653-63 [in German]

Falkenberg H, Kuhn G, Hartung M, Langhammer M, Wolf C (1999) Level of the metabolic substances in blood in relation to the development of pigs with different capacity for lipid deposition. Arch Tierz 42, 149-59

Falkenberg H, Ritter E (1992) The spermatological productivity of Al boars. Arch Tierz 35, 263-72 [in German]

Falkenberg H, Ritter E (1994) Relations between morphological and biochemical sperm characteristicsin boars and farrowing performance in sows. Arch Tierz 37, 287-300 [in German]

Grizard G, Sion B, Jouanel P, Benoit P, Boucher D (1995) Cholesterol phospholipids and markers of the function of the accessory sex glands in the semen of men with hypercholesterolemia. Int J Androl $18,151-6$

Hall JC, Hadley J, Doman T (1991) Correlation between changes in rat sperm membrane lipids protein and the membrane physical state during epididymal maturation. J Androl 12,76-87

Janik A (1997) Level of cholesterol and triglycerides in blood serum of pigs with various LPR lipoprotein genotypes. Rocz Nauk Zoot 24, 9-17 [in Polish]

Kawęcka M (2002) Relationships between growth rate and meatiness of young boars of sire populations and their reproductive usefulness. Habil Thesis AR Szczecin 206 [in Polish]

Kołodziej A, Kawęcka M, Jacyno E, Pietruszka A (2006) Relationship between cholesterol concentration in the blood serum of young boars and their fattening slaughter and reproductive performance. Ann Anim Sci Suppl 2/1, 91-4

Kommisrud E, Paulenz H, Sehested E, Grevle IS (2002) Influence of boar and semen parameters on motility and acrosome integrity in liquid boar semen stored for five days. Acta Vet Scand 43, 49-55

Labbé C, Bussière JF, Guillouet P, Leboeuf B, Magistrini M (2001) Cholesterol/phospholipids ratio in sperm of several domestic species does not directly predict sperm fitness for cryopresevation. Gen Sel Evol Suppl 33, 61-74 
Lopez MI, De Souza W (1991) Distribution of filipin-sterol complexes in the plasma membrane of stallion spermatozoa during the epididymal maturation process. Mol Reprod Dev 28, 158-68

Mack SR, Everingham J, Zaneveld LJD (1986) Isolation and partial characterization of the plasma membrane from human spermatozoa. J Exp Zool 240, 127-36

Machal L, Kalova J, Juran P, Jer Abek S (1996) The dynamics of the relationship between ejaculate quality and cholesterol and total lipids concentration in the blood plasma in two lines of the cocks. Arch Tierz 39, 61-8

Nikolopoulou M, Soucek DA, Vary JC (1985) Changes in the lipid content of boar sperm plasma membranes during epididymal maturation. Biochim Biophys Acta 815, 486-98

Parks JE, Hammerstedt RH (1985) Developmental changes occurring in the lipids of ram epididymal spermatozoa plasma membranes. Biol Reprod 32, 653-68

Parks JE, Lynch DV (1992) Lipid composition and thermotropic phase behaviour of boar bull stallion and rooster sperm membranes. Cryobiol 29, 255-66

Polish norm of pigs nutrition (1993) The Institute Animal Physiology and Nutrition PAN Jabłonna, 1-83 [in Polish]

Pursel VG, Johnson LA, Rampacek GB (1972) Acrosome morphology of boar spermatozoa incubated before cold shock. J Anim Sci 34, 55-64

Ribeiro EL, Kittok RJ, Nielsen MK (1994) Serum cholesterol concentration of mice selected for litter size and its relationship to litter size and testis mass. J Anim Sci 72 (1994) 2943-7

Schilling E, Vengust M (1987) Frequency of semen collection in boars and quality of ejaculates as evaluated by the osmotic resistance of acrosomal membrane. Anim Repr Sci 56, 1065-76

Sofikitis N, Miyagawa I (1991) Secretory dysfunction of the male accessory genital glands due to prostatic infections and fertility: a selected review of the literature. Jpn Fertil Steril 36, 690-9

Strzeżek J (1999) Reproductive physiology of the boar. Nowa Weterynaria 4, 39-47 [in Polish]

Wise T, Young LD, Pond WG (1993) Reproductive endocrine and organ weight differences of swine selected for high or low serum cholesterol. J Anim Sci 71, 2732-8

Yanagimachi R (1994) Mammalian fertilization. In: Knobil E, Neill JD (eds): Physiology of Reproduction 2nd ed, Raven Press Ltd, New York 189-317

Yeagle PL (1993) Cholesterol and the cell membrane. Biochim Biophys Acta 822, 267-87

Young LD, Leymaster KA, Lunstra DD (1986) Genetic variation in testicular development and its relationship to female reproductive traits in swine. J Anim Sci 63, 17-26

Corresponding author:

Prof.Dr. habil. EUGENIA JACYNO

email: eugenia.jacyno@biot.ar.szczecin.pl

Departement of Pig Breeding, University of Agriculture, Dr Judyma 10 st., 71-460 Szczecin, Poland 